\title{
Penentuan Kebijakan Waktu Optimum Perbaikan Komponen Mesin Finish Mill di PT. Semen Indonesia, Tbk Plant Tuban
}

\author{
Muhammad Mashuri, Diaz Fitra Aksioma, dan Ayub Samuel Yosepha \\ Departemen Statistika, Fakultas MIPA, Institut Teknologi Sepuluh Nopember (ITS) \\ e-mail:m_mashuri@statistika.its.ac.id,diaz_fa@statistika.its.ac.id,johannjoseph13@gmail.com
}

\begin{abstract}
Abstrak-Sebagai penunjang proses produksi, mesin merupa-kan komponen utama. Mesin yang baik adalah mesin yang mam-pu menghasilkan output produksi dengan input yang minimal, namun juga memiliki sistem yang berjalan baik. PT. Semen Indonesia, Tbk Plant Tuban sebagai salah satu perusahaan industri penghasil semen berusaha memenuhi kebutuhan semen nasional. Dalam mencapai kebutuhan nasional, diperlukan sistem mesin yang memiliki kehandalan tinggi. Preventive maintenance dipilih sebagai salah satu aspek untuk meminimalisir kerusakan mesin yang dilakukan secara periodik. Tak jarang pula corrective maintenance dilakukan apabila ternyata masih terjadi kerusakan di sistem mesin. Dikarenakan corrective maintenance, biaya yang ditimbulkan semakin tinggi. Salah satu mesin yang memiliki kerusakan paling sering di perusahaan adalah mesin finish mill. Berdasarkan permasalahan tersebut, maka diperlukan metode untuk menyelesaikan permasalahan di perusahaan. Salah satu metode yang digunakan adalah analisisi reliabilitas. Analisis reliabilitas merupakan metode yang digunakan untuk untuk menghitung peluang suatu mesin bekerja dengan baik pada waktu dan kondisi tertentu. Komponen yang digunakan adalah fungsi reliabilitas, laju kerusakan dan MTTF serta estimasi waktu preventive berda-sarkan biaya minimum. Berdasarkan perhitungan estimasi biaya dan waktu minimum, didapatkan waktu preventive yang disarankan untuk mesin finish mill 5 pada waktu 2250 jam dengan biaya paling minimum adalah Rp. 4.765.954.57. Sedangkan mesin finish mill 6, estimasi waktu preventive yang disarankan pada waktu 2500 jam dengan biaya paling minimum sebesar Rp. 4.074.874,83.
\end{abstract}

Kata Kunci-Analisis Reliabilitas, Estimasi Waktu Berdasarkan Biaya Minimum, Laju Kerusakan, Mean Time to Failure, Mesin Finish Mill, Preventive Maintenance.

\section{PENDAHULUAN}

$\mathrm{K}$ EBUTUHAN terhadap semen diprediksi akan mengalami peningkatan dari tahun ke tahun. Kenaikan ini diprediksi akan mengalami kenaikan hingga tahun 2017. Salah satu penyebab kenaikan tersebut dikarenakan adanya pembangunan infrastruktur yang sedang dilakukan pihak pemerintah maupun pihak swasta. Data tersebut diperoleh dari Asosiasi Semen Indonesia pada tahun 2013. Dikarenakan adanya peningkatan permintaan semen di Indonesia membuat perusahaan penghasil semen di Indonesia bersaing secara ketat. Perusahaan melakukan produksi yang lebih tinggi pada tahun-tahun sebelumnya sehingga diperlukan penunjang produksi yang juga bisa memenuhi kebutuhan semen di Indonesia [1].

Sebagai penunjang proses produksi diperlukan pening-katan kualitas produksi. Kualitas produksi pada umumnya dihasilkan oleh suatu mesin yang memiliki spesifikasi yang baik. Proses produksi memerlukan mesin yang memiliki ke-handalan yang baik. Mesin yang baik adalah mesin yang mampu menghasilkan produksi yang baik dengan input yang minimum dan memiliki kehandalan mesin yang baik pula. Untuk mencapai tujuan tersebut, diperlukan pengontrolan terhadap mesin-mesin tersebut. Apabila ditemukan suatu kerusakan, dapat dilakukan tindakan perbaikan atau maintenance. Maintenance atau pemeliharaan merupakan suatu kegiatan yang dilakukan secara berulang dan terjadwal dengan tujuan agar peralatan selalu memiliki kondisi yang sama seperti keadaan awal saat mesin melakukan proses produksi [2].

PT. Semen Indonesia, Tbk Plant Tuban sebagai salah satu perusahaan penghasil semen mengalami permasalahan dalam memenuhi target produksi serta pengeluaran biaya perawatan. Pabrik penghasil semen berkompetisi dengan ketat dimana mesin menjadi sektor yang sangat penting. Waktu downtime mesin menjadi hal yang sangat perlu diperhatikan secara bijak. Sebelum mesin melakukan kegiatan breakdown, perusahaan biasanya akan melakukan maintenance atau perawatan berupa planned preventive maintenance yang bertujuan untuk mengganti atau overhaul pada mesin tersebut. Mesin-mesin produksi yang terdapat di PT. Semen Indonesia, Tbk Plant Tuban merupakan mesin dengan spesifikasi terbaru dan tercanggih dibandingkan dengan mesin-mesin di perusahaan lainnya. Namun PT. Semen Indonesia, Tbk Plant Tuban kadangkala masih belum mencapai target produksi yang direncanakan. Hal ini disebabkan oleh reliabilitas mesin yang masih rendah. Mesin-mesin pada PT. Semen Indonesia, Tbk Plant Tuban sering mengalami kerusakan dengan selang waktu singkat setelah mendapat perbaikan [3]. Kebijakan maintenance yang diterapkan oleh PT. Semen Indonesia, Tbk Plant Tuban adalah preventive maintenance. Namun tak jarang corrective maintenance juga dilakukan ketika ditengah perjalanannya mesin mengalami kerusakan sehingga biaya maintenance yang dikeluarkan untuk PT. Semen Indonesia, Tbk Plant Tuban lebih tinggi. Sebagai bentuk evaluasi dan peningkatan performance mesin finish mill, dapat dilakukan penelitian menggunakan analisis reliabilitas.

Analisis Reliabilitas adalah peluang suatu mesin untuk bekerja dengan sebagaimana mestinya pada waktu dan kondisi tertentu. Pada dasarnya analisis reliabilitas merupakan suatu metode untuk mengetahui umur suatu mesin sehingga dapat ditentukan kapan mesin memerlukan maintenance atau perawatan. Komponen-komponen penting dalam analisis reliabilitas antara lain laju kerusakan, mean time to failure (MTTF), dan fungsi reliabilitas. Dengan mengetahui informasi tersebut, dapat disusun sebuah rencana pemeliharaan untuk 
menanggulangi kerusakan mesin yang dapat terjadi atau sering disebut preventive maintenance.

Perencanaan perawatan mesin finish mill dilakukan secara preventive maintenance di PT. Semen Indonesia, Tbk Plant Tuban telah terjadwal secara periodik, namun sering kali dilakukan diluar jadwal karena mesin mengalami kerusakan, oleh karena itu penelitian ini bertujuan untuk melakukan perencanaan perawatan berdasarkan analisis reliabilitas suatu mesin sehingga dapat mengurangi biaya perawatan dan memaksimalkan produksi yang dapat memberikan keuntungan maksimal bagi perusahaan.

\section{TINJAUAN PUSTAKA}

\section{A. Pengujian Distribusi}

Dalam Pengujian distribusi dilakukan sebagai langkah sebelum menentukan elemen reliabilitas. Metode yang digunakan untuk menguji distribusi data yaitu menggunakan pengujian uji kolmogorov-smirnov.

$$
\begin{aligned}
& H_{0}: F(x)=F_{n}(x) \\
& H_{1}: F(x) \neq F_{n}(x)
\end{aligned}
$$

Statistik Uji :

$$
D=\sup \left|F_{n}(x)-F(x)\right|
$$

dengan $F_{n}(x)$ : Fungsi distribusi empiris

$F(x)$ : Fungsi distribusi tertentu

$D_{n, a}$ : Nilai kritis uji kolmogorov-smirnov berdasarkan derajat bebas $(n)$ dan alfa $(\alpha)$ pada tabel kolmogorov-smirnov atau biasa disebut $D$-tabel.

D : Nilai hitung statistik uji kolmogorov-smirnov atau biasa disebut $D$-hitung.

Jika nilai $D$-tabel lebih besar dari $D$-tabel atau $D>D_{n, a}$ maka keputusannya adalah Tolak $H_{0}$ dengan tingkat signifikansi $5 \%[4]$.

\section{B. Maximum Likelihood Estimation (MLE)}

Maximum Likelihood Estimation (MLE) merupakan metode penaksiran parameter dengan cara memaksimumkan fungsi likelihood pada suatu persamaan. Misalkan terdapat $T_{1}, T_{2}, \ldots, T_{n}$ yang merupakan sampel acak yang saling bebas dari suatu distribusi dengan fungsi kepadatan peluang antara $t_{1}, t_{2}, \ldots, t_{n}$ adalah $f\left(t_{1}, t_{2}, \ldots, t_{n} ; \theta\right)$. Jika fungsi kepadatan peluang gabungan tersebut dinyatakan sebagai fungsi terhadap $\theta$ maka dinamakan fungsi likelihood yang dinotasikan $L$ atau ditulis sebagai berikut.

$$
L\left(t_{1}, t_{2}, \ldots, t_{n} ; \theta\right)=\prod_{i=1}^{n} f\left(t_{i}, \theta\right)
$$

dengan melakukan perhitungan model dugaan yang diperoleh dari persamaan 8 dari distribusi Weibull 3P, maka didapatkan fungsi likelihood pada persamaan 3 .

$$
L\left(t_{1}, t_{2}, \ldots, t_{n} ; \theta\right)=\left(\frac{m}{\theta^{m}}\right)^{n} \sum_{i=1}^{n}\left(t_{i}-\gamma\right)^{m-1} \exp \left[-\sum_{i=1}^{n}\left(\frac{t_{i}-\gamma}{\theta}\right)^{m}\right]
$$

jika $\hat{\theta}=\hat{\theta}\left(t_{1}, t_{2}, \ldots, t_{n}\right)$ adalah fungsi pengamatan dari sampel acak $t_{1}, t_{2}, \ldots, t_{n}$ yang merupakan nilai estimasi $\theta$, maka $\hat{\theta}=\hat{\theta}\left(t_{1}, t_{2}, \ldots, t_{n}\right)$ disebut sebagai Maximum Likelihood Estimation (MLE) dari $\theta$.
Sebagai langkah kedua, persamaan (3) dirubah ke dalam bentuk logaritma natural sebagai berikut.

$$
\ln L\left(t_{1}, t_{2}, \ldots, t_{n} ; \theta\right)=\ln \prod_{i=1}^{n} f\left(t_{i}, \theta\right)
$$

Selanjutnya persamaan (3) diturunkan terhadap $\theta_{i}$ sehingga dinyatakan sebagai berikut.

$$
\frac{\partial \ln L\left(t_{1}, t_{2}, \ldots, t_{n} ; \theta\right)}{\partial \theta}=0
$$

dengan $i=1,2,3, \ldots, n$. Untuk mengecek fungsi telah mencapai kondisi optimum, maka persamaan (3) diturunkan kembali terhadap $\theta_{i}$ dan dinyatakan dalam persamaan berikut.

$$
\frac{\partial^{2} \ln L\left(t_{1}, t_{2}, \ldots, t_{n} ; \theta\right)}{\partial^{2} \theta}<0
$$

apabila turunan kedua bernilai negatif atau kurang dari nol, maka fungsi dinyatakan mencapai kondisi optimum[7].

\section{Analisis Reliabilitas}

Uji Reliabilitas merupakan suatu peluang dimana suatu mesin akan berjalan dengan baik pada satuan waktu tertentu. Dalam analisis reliabilitas terdapat beberapa komponen yaitu.

\section{Fungsi Reliabilitas}

Fungsi reliabilitas merupakan fungsi komponen berjalan dengan baik dalam satuan waktu[6].

$$
R(t)=\int_{t}^{\infty} f(t) d t
$$

a. Distribusi Generalized Logistics.

$$
\begin{aligned}
& f(z)=\left\{\begin{array}{lr}
\frac{(1+k z)^{-1-1 / k}}{\sigma\left(1+(1+k z)^{-1 / k}\right)^{2}}, k \neq 0 \\
\frac{\exp (-z)}{\sigma(1+\exp (-z))^{2}}, k=0
\end{array} \quad \begin{array}{r}
k \neq 0 \\
k=0
\end{array}\right. \\
& \text {, dimana } z \equiv \frac{t-\mu}{\sigma} \\
& R(t)=\frac{1}{1+(1+k z)^{-1 / k}} \\
& \text { MTTF }=\int_{0}^{\infty} R(t) d t=\int_{0}^{\infty} 1-F(t) d t \\
& \text { Mean Time to Failure } \\
& \text { MTTF }=\int_{0}^{\infty} 1-\frac{1}{1+(1+k z)^{-1 / k}} d z \text {, dimana } z \equiv \frac{t-\mu}{\sigma}
\end{aligned}
$$

b. Distribusi Weibull 3P.

$$
\begin{gathered}
f(t)=\frac{m}{\theta}\left(\frac{t-\gamma}{\theta}\right)^{m-1} \exp \left[-\left(\frac{t-\gamma}{\theta}\right)^{m}\right] \\
R(t)=\exp \left[-\left(\frac{t-\gamma}{\theta}\right)^{m}\right] \\
M T T F=\gamma+\theta \Gamma\left(1+\frac{1}{m}\right)
\end{gathered}
$$

\section{Laju Kerusakan}

Laju kerusakan merupakan kecepatan suatu mesin atau komponen menjadi rusak atau tidak berfungsi persatuan wak- 
tu. Secara matematis laju kerusakan (h) memiliki persamaan sebagai berikut :

$$
h(t)=\frac{f(t)}{R(t)}
$$

dimana $f(t)$ merupakan fungsi padat peluang dalam satuan waktu (t) dari suatu data dan $\mathrm{R}(\mathrm{t})$ merupakan fungsi reliabilitas[5].

\section{Ekspektasi Biaya Dan Waktu Preventive Maintenance}

Untuk Optimasi Optimasi waktu dan biaya preventive maintenance berdasarkan usia pakai (lifetime) dapat diperoleh dengan menggunakan rumus sebagai berikut

$$
C\left(t_{p}\right)=\frac{C_{p} \times R\left(t_{p}\right)+C_{f} \times M\left(t_{p}\right)}{t_{p} \times R\left(t_{p}\right)+\int_{-\infty}^{t_{p}} t f(t) d t} \mathrm{~N}
$$

Dengan keterangan sebagai berikut,

$C_{p} \quad$ : Biaya preventive

$C_{f}$ : Biaya kerusakan

$R\left(t_{p}\right)$ : Fungsi reliabilitas mesin

$t_{p} \quad$ : Waktu preventive

$f(t)$ : Fungsi padat peluang dari distribusi data

$$
M\left(t_{p}\right) \quad: \text { Merupakan } 1-R\left(t_{p}\right)
$$

\section{E. Mesin Finish Mill}

Produksi semen dilakukan di empat area utama yakni Crusher, Rawmill, Kiln dan Finishmill. Crusher merupakan area produksi awal (pencampuran). Tahap awal pembuatan semen dimulai dengan menambang batu kapur serta tanah liat, yang dilanjutkan dengan pencampuran kedua material utama. Penambahan bahan tambahan seperti pasir silika dan copper slag dilakukan sesuai spesifikasi produk. Rawmill merupakan area produksi tahap kedua. Campuran batu kapur serta tanah liat, pasir silika, dan copper slag digiling di mesin penggilingan bahan baku (Raw-mill) hingga mencapai kehalusan 90 mikron. Kiln merupakan area produksi ketiga yakni tahap pembakaran. Hasil pembakaran pada mesin Kiln berupa butiran-butir-an yang dinamakan terak atau clinker. Wujud akhir terak adalah berupa butiran berwarna hitam. Finishmill merupakan area terakhir pada proses produksi semen. Hasil dari penggilingan akhir berupa semen disimpan di dalam silo penyimpanan semen [1]. Sistem mesin produksi di PT. Semen Indonesia, Tbk Plant Tuban dapat dijelaskan oleh Gambar 1 sebagai berikut.

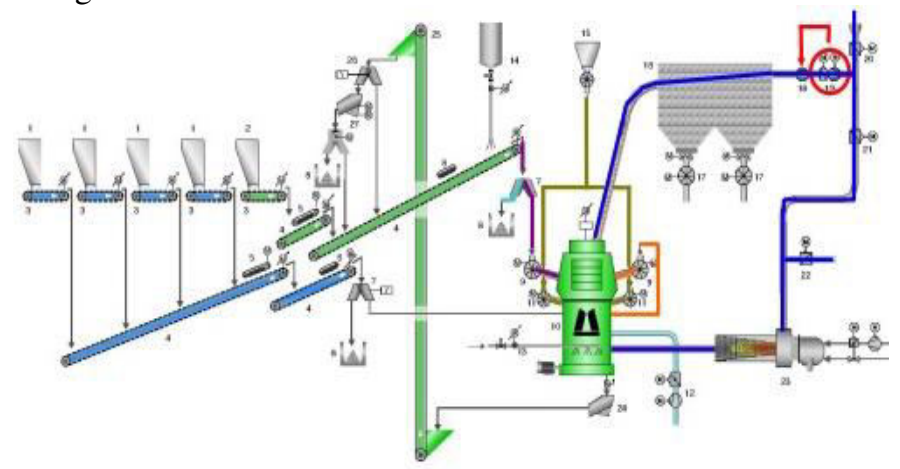

\section{METODOLOGI PENELITIAN}

\section{A. Sumber Data dan Variabel Penelitian}

Data yang digunakan pada penelitian ini adalah data sekunder dari data lama mesin bekerja dengan baik atau umur dari mesin Finish Mill yang terdapat pada PT. Semen Indonesia, Tbk Tuban Plant selama kurun waktu mulai bulan Januari 2012- Desember 2016. Variabel yang digunakan dalam penelitian ini adalah lamanya mesin bekerja (lifetime) dalam satuan jam dan data perbaikan kerusakan mesin (downtime) dalam satuan jam.

Struktur data yang digunakan dalam penelitian ini ditampilkan dalam Tabel 1 berikut.

Tabel 1.

Struktur Data Kerusakan Mesin

\begin{tabular}{ccccc}
\hline \hline \multirow{2}{*}{$\begin{array}{c}\text { Data kerusakan } \\
\text { ke- }\end{array}$} & \multicolumn{2}{c}{ Lama Mesin Bekerja } & \multicolumn{2}{c}{$\begin{array}{c}\text { Lama Perbaikan } \\
\text { Kerusakan }\end{array}$} \\
\cline { 2 - 5 } 1 & Mesin 5 & Mesin 6 & Mesin 5 & Mesin 6 \\
2 & $x_{1,1}$ & $x_{2,1}$ & $y_{1,1}$ & $y_{2,1}$ \\
$\vdots$ & $x_{1,2}$ & $x_{2,2}$ & $y_{1,2}$ & $y_{2,2}$ \\
$\mathrm{~N}$ & $\ldots$ & $\ldots$ & $\ldots$. & $\ldots$ \\
\hline \hline
\end{tabular}

\section{B. Langkah Penelitian}

Langkah-langkah analisis yang dilakukan untuk mencapai tujuan dari penelitian adalah sebagai berikut.

1. Mengumpulkan data performa mesin finish mill (Downtime dan Lifetime) pada kurun waktu tertentu.

2. Mendeskripsikan data performa mesin finish mill di PT. Semen Indonesia, Tbk Plant Tuban.

3. Menguji distribusi yang sesuai dengan data dari masingmasing mesin finish mill di PT. Semen Indonesia, Tbk Plant Tuban.

4. Menguji parameter distribusi dari masing-masing mesin finish mill yang telah sesuai dengan hasil pengujian distribusi.

5. Mendapatkan fungsi reliabilitas untuk masing-masing mesin finish mill di PT. Semen Indonesia, Tbk Plant Tuban.

6. Membuat kurva optimasi untuk menentukan waktu pemeliharaan yang meminimumkan biaya kerusakan mesin $f i$ nish mill di PT. Semen Indonesia, Tbk Plant Tuban.

7. Mendapatkan nilai waktu minimum dan biaya minimum dengan menggunakan plot (kurva).

\section{HASIL DAN PEMBAHASAN}

\section{A. Karakteristik Data Mesin Finish Mill}

Di PT. Semen Indonesia, Tbk Plant Tuban memiliki sembilan mesin di empat pabrik berbeda yang semuanya digunakan secara paralel. Penelitian ini dilakukan dengan menggunakan analisis reliabilitas. Berikut ini akan dijelaskan karakteristik data lifetime (jam) dan downtime (jam) mesin finish mill untuk mesin finish mill 5 dan finish mill 6 di pabrik Tuban 3. 
Tabel 2.

Statistika Deskriptif Lifetime dan Downtime Mesin Finish Mill

\begin{tabular}{ccccccc}
\hline \hline Variabel & Mesin & $\mathrm{N}$ & Mean & Variance & Min. & Max. \\
\hline Lifetime & 5 & 20 & 1815 & 5635514 & 8 & 8082 \\
& 6 & 12 & 3363 & 17028504 & 16 & 13136 \\
& 5 & 20 & 2.574 & 9.339 & 0.833 & 14.783 \\
Downtime & 6 & 12 & 2.643 & 3.993 & 0.58 & 7.4 \\
\hline \hline
\end{tabular}

Mesin 6 memiliki rata-rata lifetime paling lama dibandingkan dengan mesin 5 dikarenakan mesin 6. Rata-rata lifetime mesin 6 sebesar 3363 jam pada kerusakan berikutnya, sebaliknya mesin 5 memiliki rata-rata lifetime sebesar 1815 jam pada kerusakan berikutnya. Mesin 5 mengalami kerusakan sebanyak 20 kali dalam periode 2012-2016 yang lebih banyak terjadi dibandingkan mesin 6 yaitu 12 kerusakan pada periode yang sama. Namun mesin 6 memiliki rata-rata downtime yang lebih banyak dari mesin 5 yaitu 2,643 jam per kerusakan. Sedangkan mesin 5 memiliki rata-rata downtime sebesar 2,574 jam per kerusakan.

Jika dikaitkan hubungan antara variabel lifetime dan downtime, maka perlu diperhatikan adalah mesin 6 dikarenakan mesin finish mill 6 memiliki rata-rata lifetime lebih lama tetapi memiliki rata-rata downtime yang lebih lama pula. Sehingga hal ini perlu dijadikan pertimbangan bagi perusahaan agar memberi perhatian khusus terhadap mesin finish mill 6 karena mungkin ada sesuatu yang lebih bermasalah di dalam kerja mesin finish mill.

\section{B. Penentuan Distribusi Data Lifetime Mesin Finish Mill}

Dikarenakan kedua mesin bekerja secara paralel dan saling terpisah, maka dalam penelitian ini peneliti langsung menentukan distribusi masing-masing mesin finish mill untuk mendapatkan informasi yang akurat mengenai masing-masing me$\sin$.

Penentuan distribusi data merupakan langkah awal untuk menentukan elemen reliabilitas pada suatu mesin. Dalam penelitian ini menggunakan metode Kolmogorov-smirnov untuk menduga distribusi dari suatu data.

Dari data yang telah diperoleh dari perusahaan mengenai lifetime mesin finish mill. Dengan bantuan melakukan perhitungan, didapatkan bahwa distribusi yang sesuai dengan data lifetime mesin adalah distribusi Weibull 3P. berikut keterangan pendukung.

Tabel 3. Pengujian distribusi Mesin Finish Mill

\begin{tabular}{cccc}
\hline \hline \multirow{2}{*}{ Mesin } & $D$ & $D_{n, \alpha}$ & Keputusan \\
\hline 5 & 0,09898 & 0,294 & $\mathrm{H}_{0}$ gagal ditolak \\
6 & 0,25821 & 0,375 & $\mathrm{H}_{0}$ gagal ditolak \\
\hline \hline
\end{tabular}

Tabel 3 menunjukkan bahwa nilai Dtabel lebih besar daripada nilai Dhitung pada uji Kolmogorov-smirnov, sehingga dapat diambil kesimpulan adalah gagal menolak $\mathrm{H}_{0}$ yang berarti distribusi data sesuai dengan distribusi dugaan (Weibull 3P).

\section{Analisis Reliabilitas}

\section{1) Pendugaan Parameter Distribusi}

Dalam menduga parameter ada beberapa metode yang bisa digunakan dari suatu distribusi, salah satunya adalah menggunakan Maximum Likelihood Estimator (MLE). Dengan menggunakan bantuan software maka didapatkan parameter dari distribusi untuk kedua mesin finish mill sebagai berikut.

Tabel 4.

Parameter Distribusi Mesin Finish Mill

\begin{tabular}{cccc}
\hline \hline Distribusi & Parameter & Mesin 5 & Mesin 6 \\
\hline \multirow{4}{*}{ Weibull 3P } & $m$ (shape) & 0,60489 & 0,56824 \\
& $\theta$ (scale) & 1502,1 & 1756,5 \\
& $\gamma$ (location) & 7,6833 & 15,583 \\
\hline \hline
\end{tabular}

Hasil Parameter distribusi disubtitusikan pada fungsi kepadatan peluang yang dijelaskan pada persamaan 8 . Sehingga nanti terbentuk suatu fungsi yang digunakan untuk menentukan estimasi parameter distribusi Weibull 3P.

\section{2) Fungsi Kepadatan Peluang dan Reliabilitas Lifetime}

Mesin Finish Mill

Setelah didapatkan distribusi yang sesuai dengan masingmasing mesin finish mill beserta parameter distribusinya, selanjutnya adalah mensubtitusikannya kedalam fungsi padat peluang (pdf) dari distribusi yang sudah diketahui.

Data lifetime mesin finish mill berdistribusi Weibull 3P dengan parameter $m$ (shape), $\theta$ (scale), $\gamma$ (location). Dengan mensubtitusikan nilai parameter yang didapatkan pada Tabel 4 , maka fungsi kepadatan peluang menjadi sebagai berikut.

Tabel 5.

Fungsi Kepadatan Peluang Mesin Finish Mill

\begin{tabular}{cc}
\hline \hline Mesin & Fungsi Kepadatan Peluang \\
\hline 5 & $f(t)=\frac{0,60489}{1502,1}\left(\frac{t-7,6833}{1502,1}\right)^{-0,39511} \exp \left[-\left(\frac{t-7,6833}{1502,1}\right)^{0,60489}\right]$ \\
6 & $f(t)=\frac{0,56824}{1756,5}\left(\frac{t-15,583}{1756,5}\right)^{-0,43176} \exp \left[-\left(\frac{t-15,583}{1756,5}\right)^{0,56824}\right]$ \\
\hline \hline
\end{tabular}

Setelah mensubtitusikan nilai parameter untuk fungsi kepadatan peluang, didapatkan pula fungsi reliabilitas sebagai berikut.

Tabel 6.

Fungsi Reliabilitas Mesin Finish Mill

\begin{tabular}{cc}
\hline \hline Mesin & Fungsi Reliabilitas \\
\hline 5 & reliabilitas $=\exp \left[-\left(\frac{t-7,6833}{1502,1}\right)^{0,60489}\right]$ \\
6 & reliabilitas $=\exp \left[-\left(\frac{t-15,583}{1756,5}\right)^{0,56824}\right]$ \\
\hline \hline
\end{tabular}

Dengan mengetahui fungsi kepadatan peluang (pdf) dan fungsi reliabilitasnya, maka selanjutnya dapat diketahui laju kerusakan mesin finish mill. Berikut ini nilai dari laju kerusakan untuk 2500 jam pemakaian mesin finish mill. 
Tabel 7. Persentase Laju Kerusakan Mesin Finish Mill

\begin{tabular}{ccccccc}
\hline \hline $\begin{array}{c}\text { Waktu } \\
\text { (jam) }\end{array}$ & 100 & 500 & 1000 & 1500 & 2000 & 2500 \\
\hline Mesin 5 & $0,121 \%$ & $0,062 \%$ & $0,047 \%$ & $0,041 \%$ & $0,036 \%$ & $0,033 \%$ \\
Mesin 6 & $0,120 \%$ & $0,058 \%$ & $0,044 \%$ & $0,038 \%$ & $0,034 \%$ & $0,032 \%$ \\
\hline \hline
\end{tabular}

Berdasarkan Tabel 7 dapat dilihat bahwa nilai laju kerusakan mesin finish mill dari jam pemakaian mengalami penurunan khususnya saat mesin bekerja di 100 jam pertama.

Selain laju kerusakan mesin, elemen lain yang digunakan untuk mengetahui kehandalan mesin adalah dengan menghitung nilai reliabilitas dari mesin tersebut. Berikut adalah nilai reliabilitas mesin finish mill untuk 2500 jam.

Tabel 8.

Persentase Reliabilitas Mesin Finish Mill

\begin{tabular}{ccccccc}
\hline \hline $\begin{array}{c}\text { Waktu } \\
\text { (jam) }\end{array}$ & 100 & 500 & 1000 & 1500 & 2000 & 2500 \\
\hline $\begin{array}{c}\text { Mesin } \\
5\end{array}$ & $83,11 \%$ & $60,09 \%$ & $45,92 \%$ & $36,93 \%$ & $30,53 \%$ & $25,71 \%$ \\
$\begin{array}{c}\text { Mesin } \\
6\end{array}$ & $83,68 \%$ & $61,82 \%$ & $48,69 \%$ & $40,30 \%$ & $34,24 \%$ & $29,59 \%$ \\
\hline \hline
\end{tabular}

Dari Tabel 8 dapat diketahui bahwa nilai reliabilitas dari 100 jam pertama sampai 500 jam pertama mengalami penurunan yang cukup signifikan yaitu $20 \%$ pada 400 jam selanjutnya. Nilai reliabilitas justru mengalami penurunan signifikan saat mesin finish mill bekerja pada lebih dari 100 jam pertama. Hal ini menunjukkan bahwa mesin finish mill diperlukan adanya tindakan maintenance sebelum terjadi sesuatu hal yang tidak diinginkan oleh perusahaan.

\section{Perhitungan Perbaikan Kerusakan dan Perbaikan Preven-} tive

Dalam suatu perencanaan perbaikan (maintenance), salah satu hal yang wajib diperhatikan adalah perihal pembiayaan yang nantinya akan timbul dari perbaikan itu sendiri. Selanjutnya akan dibahas mengenai optimasi selang waktu perbaikan yang tepat sehingga dapat meminimumkan biaya.

1) Perhitungan Waktu Preventive dan Estimasi Biaya Perbaikan Mesin Finish Mill 5

Untuk menentukan waktu preventive diperlukan adanya perencanaan yang bisa meminimumkan biaya perawatan. Sebelum menentukan waktu preventive dan estimasi biaya, terlebih dahulu menentukan nilai Cf (Cost of Failure) dan Cp (Cost of Preventive). Berikut ini adalah hasil perhitungan untuk nilai $\mathrm{Cf}$ dan $\mathrm{Cp}$.

Tabel 9.

Nilai $c_{p}$ dan Nilai $c_{f}$

\begin{tabular}{crr}
\hline \hline Rata-rata downtime per bulan & \\
\hline Loss Production per bulan & & 2.57 \\
Harga semen per ton & Rp. & 9887.71 ton \\
Cost of Failure (Cf) per bulan & Rp. 3.647.295.041.67 \\
Cost of Preventive per bulan & Rp. 1.340.574.241.67 \\
\hline \hline
\end{tabular}

Setelah mengetahui nilai $\mathrm{Cf}$ dan $\mathrm{Cp}$, selanjutnya adalah mensubtitusikan nilai tersebut kedalam persamaan, dengan $\mathrm{R}(\mathrm{tp})$ dan $\mathrm{M}(\mathrm{tp})$ merupakan fungsi untuk distribusi Weibull 3P. Berikut ini hasil subtitusinya.

$$
C\left(t_{p}\right)=\frac{R p \cdot 1.340 .574 .241,67 \times R\left(t_{p}\right)+R p \cdot 3.647 .295 .041,67 \times M\left(t_{p}\right)}{t_{p} \times R\left(t_{p}\right)+\int_{0}^{t_{p}} f(t) d t}
$$

Untuk memudahkan dalam mendapatkan nilai $\mathrm{C}(\mathrm{tp})$, digunakan bantuan dari Microsoft excel dengan berbagai nilai tp. Berikut ini ditampilkan plot nilai tp dan nilai C(tp).

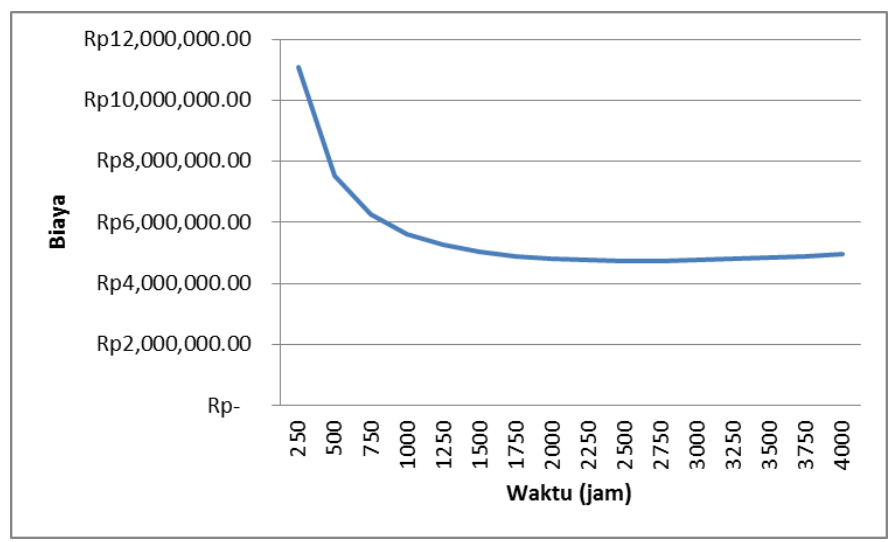

Gambar 2. Plot Nilai tp dan C(tp) Mesin Finish Mill 5.

Nilai estimasi biaya minimum didapatkan dengan mencari titik balik (turning point) pada suatu kurva. Berdasarkan Gambar 2 dapat dilihat bahwa terdapat titik balik pada saat tp bernilai 2250 jam dengan estimasi biaya minimum sebesar Rp. 4.765.954,57 per jam kerusakan. Waktu preventive ini lebih baik dibandingkan waktu yang dilakukan oleh perusahaan. Biaya estimasi dari waktu preventive juga lebih minimum dibandingkan dengan waktu preventive maintenance sebesar $\mathrm{Rp}$ 1.340.574.241,67 per bulan. Nilai tp tersebut sesuai jika mengacu pada nilai MTTF yang didapatkan pada subbab C dari mesin finish mill 5 yaitu 2242,7677 jam, dimana nilai waktu preventive kurang dari nilai MTTF.

2) Perhitungan Waktu Preventive dan Estimasi Biaya Perbaikan Mesin Finish Mill 6

Untuk menentukan waktu preventive diperlukan adanya perencanaan yang bisa meminimumkan biaya perawatan. Sebelum menentukan waktu preventive dan estimasi biaya, terlebih dahulu menentukan nilai Cf (Cost of Failure) dan $\mathrm{Cp}$ (Cost of Preventive). Berikut ini adalah hasil perhitungan untuk nilai $\mathrm{Cf}$ dan $\mathrm{Cp}$.

Tabel 10.

Nilai $c_{p}$ dan Nilai $c_{f}$

\begin{tabular}{crr}
\hline \hline Rata-rata downtime per bulan & 2.64 \\
\hline Loss Production per bulan & $10.256,3267$ ton \\
Harga semen per ton & Rp. & 948000,00 \\
Cost of Failure (Cf) per bulan & Rp. 3.682.953.666,67 \\
Cost of Preventive per bulan & Rp. 1.432.991.613,75 \\
\hline \hline
\end{tabular}

Setelah mendapatkan nilai $\mathrm{Cf}$ dan $\mathrm{Cp}$, selanjutnya adalah mensubtitusikan nilai tersebut kedalam persamaan, dengan $\mathrm{R}(\mathrm{tp})$ dan $\mathrm{M}(\mathrm{tp})$ merupakan fungsi untuk distribusi Weibull 3P. Berikut ini hasil subtitusinya.

$C\left(t_{p}\right)=\frac{R p .1 .432 .991 .613,75 \times R\left(t_{p}\right)+R p .3 .682 .953 .666,67 \times M\left(t_{p}\right)}{t_{p} \times R\left(t_{p}\right)+\int_{0}^{t_{p}} t f(t) d t}$ 
Untuk memudahkan dalam memperoleh nilai $\mathrm{C}(\mathrm{tp})$, digunakan bantuan dari Microsoft excel dengan berbagai nilai tp. Berikut ini ditampilkan plot nilai tp dan nilai $\mathrm{C}(\mathrm{tp})$.

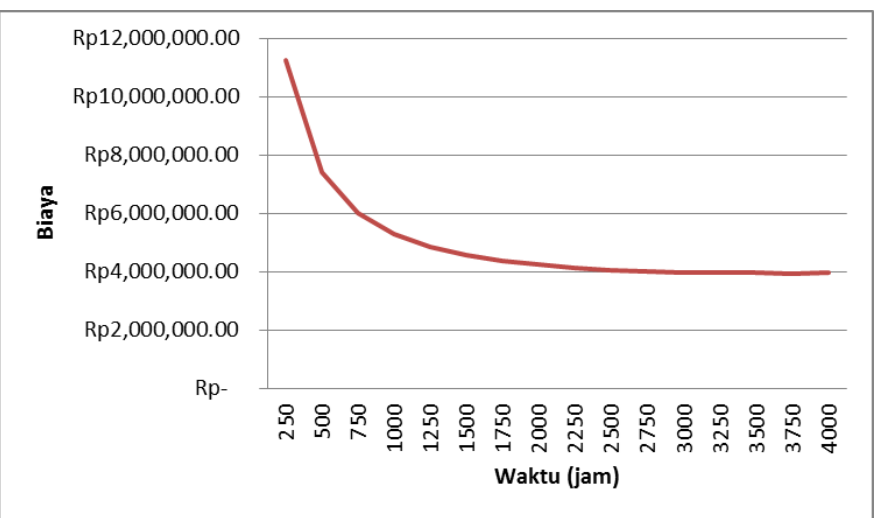

Gambar 3. Plot Nilai tp dan C(tp) Mesin Finish Mill 6.

Estimasi biaya minimum didapatkan dengan mencari titik balik (turning point) pada suatu kurva. Berdasarkan Gambar 3 dapat dilihat bahwa terdapat titik balik pada saat tp bernilai 2500 jam dengan estimasi biaya minimum sebesar Rp. 4.074.874,83 per jam kerusakan. Waktu preventive ini lebih baik dibandingkan waktu yang dilakukan oleh perusahaan. Biaya estimasi dari waktu preventive juga lebih minimum dibandingkan dengan waktu preventive maintenance sebesar Rp. 1.432.991.613,75 per bulan. Nilai tp tersebut sesuai jika mengacu pada nilai MTTF yang didapatkan pada subbab C dari mesin finish mill 6 yaitu 2856,51 jam, dimana nilai waktu preventive kurang dari nilai MTTF.

\section{KESIMPULAN DAN SARAN}

Berdasarkan hasil analisis dan pembahasan, dapat disimpulkan bahwa karakteristik data lifetime dan downtime masing-masing mesin finish mill 5 dan finish mill 6 berbeda. Berdasarkan rata-rata lifetime dan rata-rata down-time, mesin finish mill 6 perlu diperhatikan. Hal ini dikarenakan mesin finish mill 6 memiliki rata-rata lifetime lebih lama namun sering mengalami kerusakan sehingga membutuhkan waktu perbaikan yang lama. Berdasarkan data lifetime mesin finish mill maka distribusi yang sesuai adalah Weibull 3P. Estimasi parameter yang diperoleh untuk masing-masing mesin finish mill berbeda. Hal ini diperoleh karena mesin finih mill 5 dan 6 memiliki lifetime dan total kerusakan yang berbeda. Perhitungan estimasi biaya dan waktu perbaikan minimum, didapatkan estimasi waktu perbaikan sebelum terjadi kerusakan untuk mesin finish mill 5 pada waktu 2250 jam dengan biaya paling minimum sebesar Rp. 4.765.954,57 per jam perbaikan. Sedangkan mesin finish mill 6, estimasi waktu perbaikan yang disarankan sebelum terjadinya kerusakan yaitu pada 2500 jam dengan biaya paling minimum sebesar Rp. 4.074.874,83 per jam perbaikan. Estimasi waktu dan biaya perbaikan yang disarankan lebih baik dibandingkan dengan perusahaan lakukan saat ini.

Kebijakan waktu perbaikan sebelum terjadinya kerusakan yang disarankan untuk perusahaan mencoba melakukan perbaikan setiap 2250 sampai 2500 jam sebelum mesin finish mill mengalami kerusakan. Selain itu, perlu juga dilakukan pendataan yang lebih mendetail terkait data kerusakan mesin $f i-$ nish mill agar diperoleh informasi yang lebih spesifik.

\section{DAFTAR PUSTAKA}

[1] "PT. Semen Indonesia (Persero), Tbk," 30 April 2014. [Online]. Available: www.semenindonesia.com. [Accessed 9 Februari 2016].

[2] K. Mobley, L. Higgins and D. Wikoff, in Maintenance Engginering Handbook, New York, McGraw-Hill Companies, 2008, p. Vol 7.

[3] L. A. A. D. W. Astarini and Haryono, Analisis Reliabilitas dan Avabilitas pada Mesin Produksi dengan Sistem Seri Menggunakan Pendekatan Analisis Markov di PT "X", vol. Vol. 4 No. 1, no. Statistika ITS Jurnal Sains dan Seni, 2015.

[4] Z. Govindarajulu, Nonparametrik Inference, no. World Scientific Publishing Company Incoporated, 2007.

[5] C. E. Ebeling, An Introduction to Reliability and Maintanaibility Engineering, Singapore: McGraw-Hill, 1997.

[6] B. S. Dhillon, Applied Reliability and Quality, London: Springer, 2007.

[7] R. V. Hogg and A. T. Craig, Introduction to Mathematical Statistics Fifth Edition, New York: Prentice Hall, 1995. 